\title{
Effect of curcumin and paclitaxel on breast carcinogenesis
}

\author{
EDGAR TEDDY QUISPE-SOTO ${ }^{1}$ and GLORIA M. CALAF $^{1,2}$ \\ ${ }^{1}$ Instituto de Alta Investigación, Universidad de Tarapacá, Arica 8097877, Chile; \\ ${ }^{2}$ Center for Radiological Research, Columbia University Medical Center, New York, NY 10032, USA
}

Received July 21, 2016; Accepted September 19, 2016

DOI: 10.3892/ijo.2016.3741

\begin{abstract}
Global cancer burden increased to 14.1 million new cases in 2012; and breast cancer is the most common cancer in women worldwide, with nearly 1.7 million new cases diagnosed in 2012. Curcumin is the major bioactive ingredient extracted from the rhizome of the plant Curcuma longa (turmeric). Paclitaxel is a microtubule-stabilizing agent originally isolated from the bark of Taxus brevifolia. Curcumin and paclitaxel were evaluated with two human breast cancer cell lines as the luminal MCF-7 and the basal-like MDA-MB-231 that are either positive or negative for hormonal receptors estrogen receptor, progesterone receptor and HER2, respectively. Results indicated that curcumin combined with paclitaxel decreased c-Ha-Ras, Rho-A, p53 and Bcl-xL gene expression in comparison to control and substances alone in MCF-7 cell line. These two substances alone and combined decreased gene expression of $\mathrm{Bcl}-2$ and $\mathrm{NF}-\mathrm{\kappa B}$. However, CCND1 increased when both substances were combined in MCF-7 cells. Such substances decreased $\mathrm{Bcl}-2$ and increased $\mathrm{Bax}$ protein expression. However, curcumin alone decreased $I \kappa B \alpha$ and Stat-3 gene expression. Paclitaxel alone and combined increased I $\kappa \alpha$ and Stat-3. Curcumin alone and combined with paclitaxel increased p53, Bid, caspase-3, caspase- 8 and Bax gene expression in MDA-MB-231, whereas $B c l-x L$ decreased such expression in MDA-MB-231 cells. When paclitaxel and curcumin were combined the expression of $\mathrm{Bcl}-2$ protein was decreased. However, either substance alone and combined increased Bax protein expression corroborating the apoptotic effect of these substances. It can be concluded that curcumin may be of considerable value in synergistic therapy of breast cancer reducing the associated toxicity with use of drugs.
\end{abstract}

\section{Introduction}

Global cancer burden was reported as 14.1 million new cases in 2012; breast cancer is the most common cancer in women

Correspondence to: Dr Gloria M. Calaf, Instituto de Alta Investigación, Universidad de Tarapacá, Calle Antofagasta 1520, Arica 8097877, Chile

E-mail: gmc24@cumc.columbia.edu

Key words: curcumin, paclitaxel, breast cancer cells worldwide, with nearly 1.7 million new cases were diagnosed in 2012. This represents $\sim 12 \%$ of all new cancer cases and $25 \%$ of all cancers in women (1).

Curcumin is the major bioactive ingredient extracted from the rhizome of the plant Curcuma longa Linn (turmeric). Curcumin has chemopreventive properties against various malignancies, and extensive biological and pharmacological function, for example, anticancer, antioxidant, anti-inflammatory, antibacterial, antispasmodic and anticoagulant, without any major side effects $(2,3)$. As a pharmacologically safe agent, curcumin could be used alone to prevent cancer and in combination with chemotherapy to treat cancer. Different molecular targets are modulated by curcumin. It induces apoptosis by means of the inhibition of NF- $\kappa \mathrm{B}$ activity through downregulation of upstream kinases, IKK- $\beta$ and IKK- $\alpha$ (4).

Paclitaxel is a microtubule-stabilizing agent originally isolated from the bark of Taxus brevifolia. It is a potent agent which inhibits neoplastic growth in several malignancies including ovarian, breast, non-small cell lung cancer, head and neck cancers (5-7). As with the majority of anticancer agents, paclitaxel causes cancer cell death with signs of apoptosis and also it is supposedly associated with mitotic catastrophe $(8,9)$.

c-Ha-ras is an oncoprotein corresponding to a GTP-binding protein (10). DNA transfection studies have suggested that an activated c-Ha-ras oncogene can convert human breast cancer cells to a more aggressive, estrogen-independent phenotype (11). Ras homolog gene family member A (Rho-A) is a small $(\sim 22 \mathrm{kDa}) \mathrm{G}$ protein/guanosine triphosphatase that is part of the Ras-related $\mathrm{C} 3$ botulinum toxin substrate (Rac) subfamily of the Rho family (12). Rho-A can reorganize the cell cytoskeleton and regulate cell migration by activating effector proteins such as Rho-associated coiled-coil kinase (ROCK) (13); such changes are associated with tumor invasion and migration in several types of carcinoma cells $(14,15)$. p53, the tumor suppressor protein plays a key role with respect to apoptosis but also senescence, growth arrest and DNA repair $(16,17)$.

Apoptosis is a process of programmed cell death that occurs in response to environmental stimuli and appropriated strategy for prevention and treatment of cancer (18). Gene and protein expression of Bax in breast cancer cells increase sensitivity to apoptotic stimuli and decrease tumor growth. Apoptosis is a phenomenon usually linked to the presence of functional p53 (19). Bcl-2 protein family plays an important role in the survival or death of a cell and it is a target of many 
antitumor drugs $(20,21)$. The Bcl-2 protein family, of which Bax is a member, plays a critical role in determining either cell death or survival $(22,23)$. Bax is a pro-apoptotic protein that acts as an enhancer of apoptosis while Bcl-2 has anti-apoptotic properties as Bcl-xL that inhibits apoptosis and stimulates the progress of breast cancer $(20,24)$. In particular, the balance between Bax (pro-apoptotic) and Bcl-2 (anti-apoptotic) protein levels is important for the regulation of apoptosis (25). Overexpression of Bax leads to apoptosis in the absence of any stimulus, suggesting that tight regulation of Bax, from transcription to post-translation, is necessary for cell survival (26). Anti-apoptotic Bcl-2 family members are overexpressed in a variety of cancers through genetic alterations, such as chromosomal translocation (Bcl-2) or amplification (Bcl-xL and Mcl-1) (27-29).

The nuclear factor $\kappa$-light-chain-enhancer of activated $\mathrm{B}$ cells (NF-kB) is a pro-inflammatory and pro-survival transcription factor and it is known to be highly involved in the initiation and progression of breast cancer (30). NF- $\mathrm{\kappa B}$ deregulation of activity alters the expression of cell death-regulating genes, leading to the upregulation of anti-apoptotic and pro-survival genes, such as members of the Bcl-2 family (31). Protein inhibitors of $\kappa B(\mathrm{I} \kappa \mathrm{B})$ suppress activation of NF- $\kappa \mathrm{B}$ including I $\kappa \mathrm{B} \alpha, \mathrm{I} \kappa \mathrm{B} \beta, \mathrm{I} \kappa \mathrm{B} \varepsilon$ and $\mathrm{I} \kappa \mathrm{B} \zeta(32-40)$. The aim of this study is to demonstrate the effect of curcumin and paclitaxel on gene and protein expression related to apoptosis in human breast cancer cell lines to provide new therapeutic potential of curcumin combined with paclitaxel on human breast cancer and to establish whether paclitaxel acquired chemoresistance in breast cancer cells.

\section{Materials and methods}

Cell culture conditions. Human breast carcinoma cell lines MDA-MB-231 (ATCC ${ }^{\circledR}$ HTB26 $^{\text {TM }}$ ) and MCF-7 (ATCC ${ }^{\circledR}$ $\mathrm{HTB} 22^{\mathrm{TM}}$ ) were maintained in a culture medium at $37^{\circ} \mathrm{C}$ in a humidified atmosphere of $5 \% \mathrm{CO}_{2}$ in air. The culture medium consisted of basic medium supplemented with $10 \%$ fetal bovine serum (Life Technologies, Grand Island, NY, USA). The basic medium was RPMI-1640 for MDA-MB-231 and minimum essential media (Life Technologies) for MCF-7 with $10 \mu \mathrm{g} / \mathrm{ml}$ of human insulin (Sigma-Aldrich, St. Louis, MO, USA), both supplemented with $1 \%$ penicillin-streptomycin (Life Technologies). Curcumin and paclitaxel were obtained from Sigma-Aldrich. Both substances were dissolved in dimethylsulfoxide $(0.1 \%)$. Cells were seeded after $24 \mathrm{~h}$ prior to treatment with curcumin $(15$ and $30 \mu \mathrm{M})$, paclitaxel (10-240 nM) and combination of these two drugs. All the treatments were performed at $37^{\circ} \mathrm{C}$. Cells were harvested and seeded at $4 \times 10^{4}$ cells $/ \mathrm{ml}$ of culture medium into 24-well plates (Corning Costar, Corning, NY, USA). After a 24-h pre-incubation period allowing cells to attach, the culture medium was replaced by either culture medium without drugs or medium with one of tested treatments of curcumin and/or paclitaxel at desired concentrations for $48 \mathrm{~h}$ and it was replaced by culture medium without drugs for $96 \mathrm{~h}$. Cells were stained with trypan blue (Sigma-Aldrich) with a 1:9 ratio of trypan blue for cell suspension. Cells were counted in TC20 ${ }^{\mathrm{TM}}$ Automated Cell Counter (Bio-Rad Laboratories, Hercules, CA, USA). Dark blue cells were evaluated as dead cells.
Doubling time (DT). Cell growth was observed and counted at $0,24,48$ and $96 \mathrm{~h}$ to determine doubling time (h). Upon treatment, both control and treated cells were replated as described above. Their growth was measured by determining the total number of doublings by applying the formula: Total doublings: $\mathrm{Td}=\ln 2 / \mu$ where $\mu=\ln \left(\mathrm{N}_{1} / \mathrm{N}_{0}\right) /\left(\mathrm{t}_{1}-\mathrm{t}_{0}\right)$ where $\mathrm{N}_{1}$ and $\mathrm{N}_{0}$ are the number of cells at times $t_{1}$ and $t_{0}$. $N_{1}$ is the total number of cells counted at confluence and $\mathrm{N}_{0}$ is the initial plating density. Total doublings were evaluated over multiple passages. The number of doublings was determined by dividing the total number of doublings by the number of days which each particular sample was followed. Based upon these values, the time required for the total cell number to double from any reference point, or doubling time, was calculated (41).

Reverse transcription quantitative polymerase chain reaction (RT-qPCR). Total RNA was extracted with TRIzol (Invitrogen, Carlsbad, CA, USA), and the concentration and purity of RNA were determined using a UV spectrophotometer (Thermo Scientific, Rochester, NY, USA). Total RNA was reverse transcribed into cDNA using high capacity cDNA Reverse Transcription kit (Applied Biosystems, Carlsbad, CA, USA) and $10 \mathrm{U}$ of RNase inhibitor (Applied Biosystems) according to the manufacturer's protocol. A CFX 96 Touch Real-Time PCR Detection systems (Bio-Rad Laboratories) was used with an aliquot of cDNA (2 $\mu \mathrm{l})$ in $20 \mu \mathrm{l}$ qPCR reaction containing SYBR Green PCR Master Mix (Agilent, La Jolla, CA, USA) for measurement of target genes such as c-Ha-ras, Rho-A, $p 53$, Bax, Bcl-xL, CCND1, NF- $k B, I \kappa B \alpha$, Stat-3, Bid, caspase-3 and caspase-8; and $\beta$-actin as reference to obtain the relative fold change for target genes using the comparative $\mathrm{Ct}$ method and using Bio-Rad CFX Manager 2.1 software. Table I shows the primers for the genes selected to develop cDNA probes. Relative expression was normalized to the average of controls.

Western blot analysis. Cells were lysed with $1 \mathrm{ml}$ lysis buffer (pH 7.2) [Tris Base $(50 \mathrm{mM}), \mathrm{NaCl}(100 \mathrm{mM})$, EDTA $(1 \mathrm{mM})$, Ortovanadate $(1 \mathrm{mM})$, PMSF $(1 \mathrm{mM})$, Triton X-100 (0.1\%) and centrifuged (13,200 rpm x $15 \mathrm{~min})]$. The supernatant with cellular proteins was dissolved in SDS-PAGE sample solution $(60 \mathrm{mM})$ Tris, $\mathrm{pH} 6.5,10 \%(\mathrm{w} / \mathrm{v})$ glycerol, $5 \%(\mathrm{w} / \mathrm{v})$ $\beta$-mercaptoethanol, 20\% (w/v) SDS, and $0.025 \%$ (w/v) bromophenol blue and denatured by boiling $(2 \times 5 \mathrm{~min})$, and vortex mixing $(2 \times 30 \mathrm{seg})$. The total amount of protein was $30 \mu \mathrm{g}$ in each lane with standard protein markers (Bio-Rad Laboratories). After fractionation by SDS-PAGE on gels $(7 \times 14 \mathrm{~cm})$, proteins were electro-blotted onto PVDF membrane (Amersham, Biosciences, Amersham, UK) using a blotting apparatus (Bio-Rad Laboratories). Prestained SDS-PAGE (Standards) blots were blocked for $2 \mathrm{~h}$ in $10 \%$ defatted dry milk-TBS-0.1\% Tween and then incubated for $2 \mathrm{~h}$ at room temperature with corresponding primary antibodies [1:200, Bcl-2 (sc-7382), Bax (sc-7480), and $\beta$-actin (Sigma A-5316) followed by incubation with secondary peroxidase-conjugated mouse $\operatorname{IgG}(1: 5,000)$ (Cell Signaling, CA, USA) in 5\% defatted dry milk-TBS-0.1\% Tween]. All steps were performed at room temperature, and blots were rinsed between incubation steps with TBS- $0.1 \%$ Tween. Cell blots were probed with mouse anti- $\beta$-actin antibody as control. Immunoreactive bands were visualized by using the $\mathrm{ECL}^{\mathrm{TM}}$ Western Blotting Detection Reagent 
Table I. Selected primers for target genes to develop cDNA probes.

\begin{tabular}{|c|c|c|}
\hline Gene name & Product length $(b p)^{a}$ & Primer sequence ${ }^{b}$ \\
\hline c-Ha-ras & 112 & $\begin{array}{l}\text { F: CACCAGTACAGGGAGCAGAT } \\
\text { R: GAGCCTGCCGAGATTCCACA }\end{array}$ \\
\hline Rho-A & 140 & $\begin{array}{l}\text { F: CCATCATCCTGGTTGGGAAT } \\
\text { R: CATGTACCCAAAAGCGCCA }\end{array}$ \\
\hline p53 & 128 & $\begin{array}{l}\text { F: CCTCAGCATCTTATCCGAGTGG } \\
\text { R: TGGATGGTGGTACAGTCAGAGC }\end{array}$ \\
\hline Bax & 143 & $\begin{array}{l}\text { F: GCGAGTGTCTCAAGCGCATC } \\
\text { R: CCAGTTGAAGTTGCCGTCAGAA }\end{array}$ \\
\hline$B c l-x L$ & 211 & $\begin{array}{l}\text { F: CTGAATCGGAGATGGAGACC } \\
\text { R: TGGGATGTCAGGTCACTGAA }\end{array}$ \\
\hline CCND1 & 60 & $\begin{array}{l}\text { F: GTGGCCTCTAAGATGAAGGA } \\
\text { R: GGTGTAGATGCACAGCTTCT }\end{array}$ \\
\hline$N F-\kappa B$ & 114 & $\begin{array}{l}\text { F: ATCTGCCGAGTGAACCGAAACT } \\
\text { R: CCAGCCTGGTCCCGTGAAA }\end{array}$ \\
\hline$I \kappa B \alpha$ & 135 & $\begin{array}{l}\text { F: CTCCGAGACTTTCGAGGAAATAC } \\
\text { R: GCCATTGTAGTTGGTAGCCTTCA }\end{array}$ \\
\hline Stat-3 & 163 & $\begin{array}{l}\text { F: GGTTGGACATGATGCACACTAT } \\
\text { R: AGGGCAGACTCAAGTTTATCAG }\end{array}$ \\
\hline Bid & 199 & $\begin{array}{l}\text { F: GCTTCCAGTGTAGACGGAGC } \\
\text { R: GTGCAGATTCATGTGTGGATG }\end{array}$ \\
\hline Caspase-3 & 192 & $\begin{array}{l}\text { F: CAGAACTGGACTGTGGCATTG } \\
\text { R: GCTTGTCGGCATACTGTTTCA }\end{array}$ \\
\hline Caspase-8 & 128 & $\begin{array}{l}\text { F: CATCCAGTCACTTTGCCAGA } \\
\text { R: GCATCTGTTTCCCCATGTTT }\end{array}$ \\
\hline$\beta$-actin & 569 & $\begin{array}{l}\text { F: ACTACCTCATGAAGATCCTC } \\
\text { R:TAGAAGCATTTGCGGTGGACGATGG }\end{array}$ \\
\hline
\end{tabular}

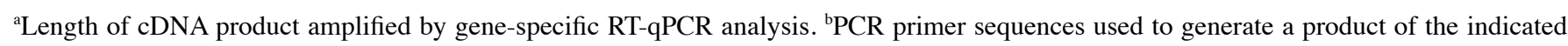
size, listed in 5'-3' orientation. F, forward; R, reverse.

detection method (Amersham, Dübendorf, Switzerland) and exposure of the membrane to X-ray film (Kodak, Rochester, NY, USA). Protein determination was performed using the Bicinchoninic Acid Method (Bio-Rad Laboratories) and BSA as the standards. Experiments were performed in triplicates.

Statistical analysis. Data were expressed as the average \pm standard error of the mean (SEM). Comparisons of multiple groups were performed between treated groups and controls carried out by ANOVA and Dunnet's test with GraphPad Prism 5 software. A $\mathrm{P}<0.05$ was considered to be significant. Assays were performed at least three times independently.

\section{Results}

Effect of curcumin and paclitaxel on DT of tumor cell lines. The DT of curcumin and paclitaxel was evaluated with two cell lines that are either positive or negative for hormonal receptors $\left(\mathrm{ER}^{+} \mathrm{PR}^{+}\right.$and $\left.\mathrm{HER} 2^{+}\right)$as the luminal $\mathrm{MCF}-7$ and the basal-like MDA-MB-231, respectively. Fig. 1 indicates that curcumin at $15 \mu \mathrm{M}$ and paclitaxel at $120 \mathrm{nM}$ had significantly $(\mathrm{P}<0.05)$ longer DT than control and substances alone with other combinations in MCF-7 cell line. On the other hand, these results showed that MDA-MB-231 cell line had significantly $(\mathrm{P}<0.05)$ longer DT with curcumin at $15 \mu \mathrm{M}$ combined with paclitaxel at 10,20 and $240 \mathrm{nM}$ as well as curcumin at $30 \mu \mathrm{M}$ with paclitaxel at $10 \mathrm{nM}$ than control and curcumin at $15 \mu \mathrm{M}$ alone. Therefore, these combinations were used for determining several important gene targets in malignancy and apoptosis. All the doses used significantly decreased the rate of growth of cells above its controls as indicated by the DT after several passages.

Effect of curcumin and paclitaxel on gene expression in MCF-7 breast cancer cells. Gene expression analyzed by RT-qPCR indicated that curcumin combined $(15 \mu \mathrm{M})$ with paclitaxel 

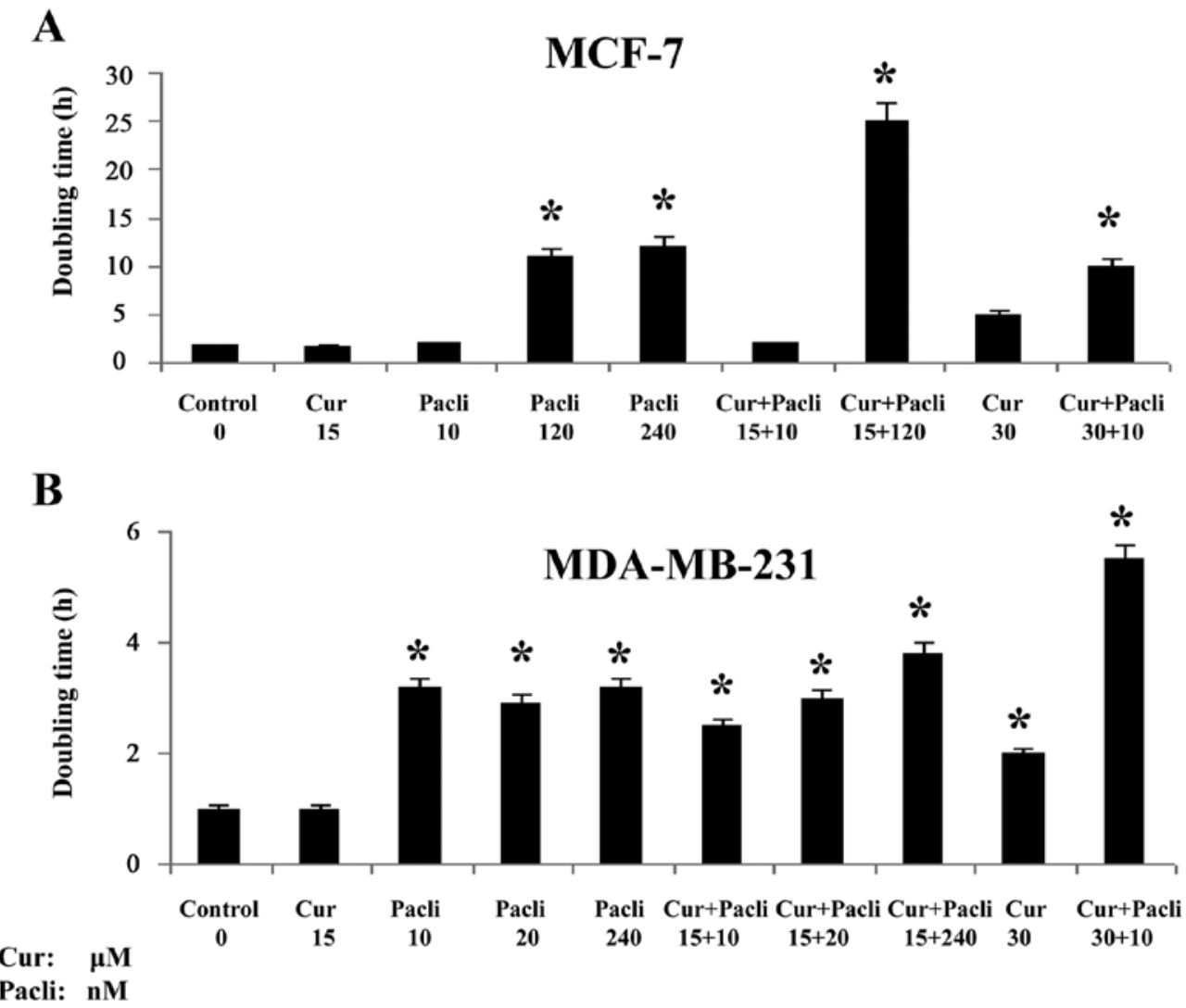

Figure 1. Doubling time of (A) MCF-7 and (B) MDA-MB-231 cell lines exposed to different doses of curcumin ( 0,15 and $30 \mu \mathrm{M})$ and paclitaxel (0, 10, 20, 120 and $240 \mathrm{nM})$. Bars represent the mean \pm SEM of three independent experiments.
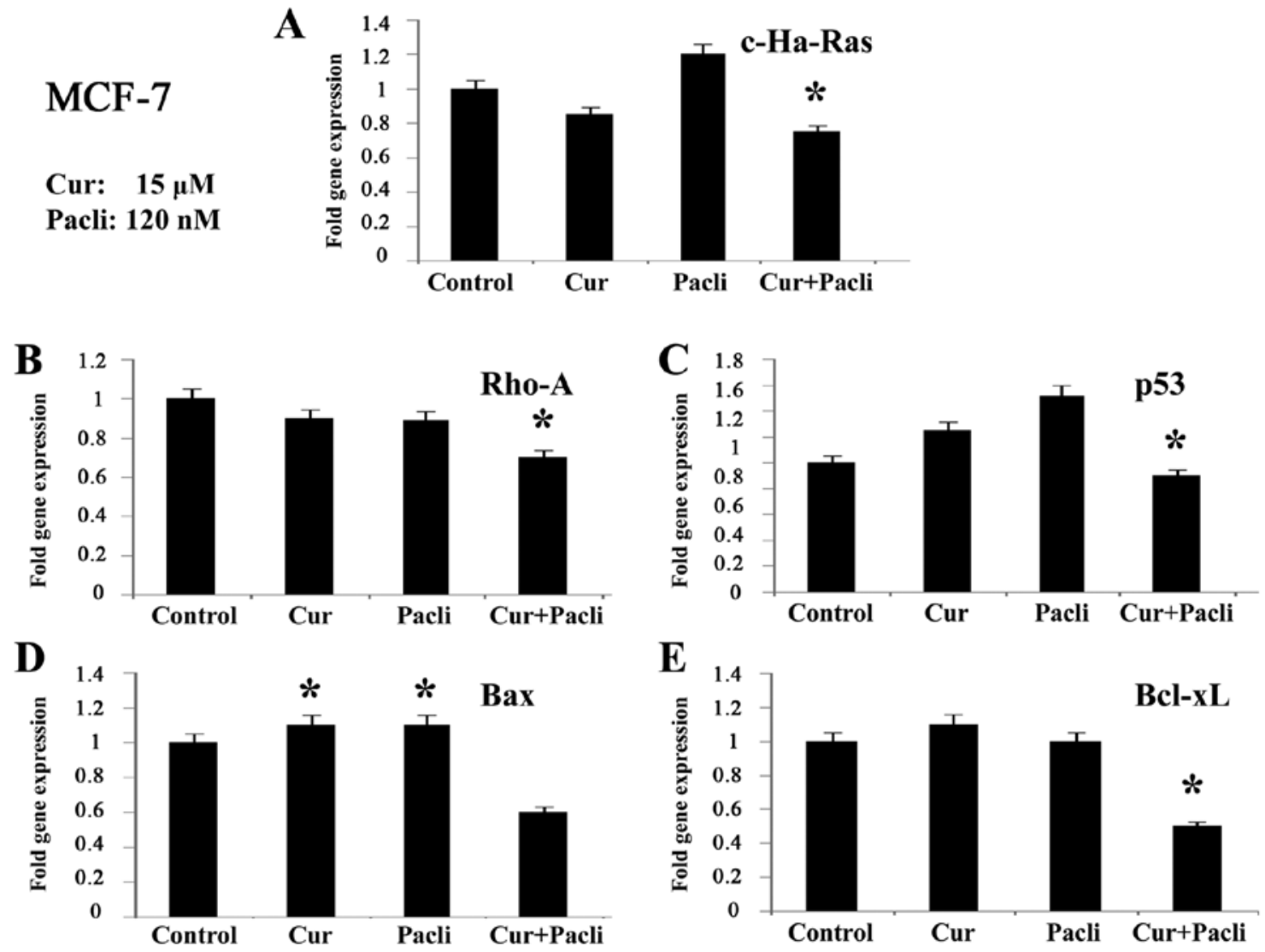

Figure 2. Effect of curcumin $(15 \mu \mathrm{M})$ and paclitaxel $(120 \mathrm{nM})$ on gene expression analyzed by RT-qPCR on (A) c-Ha-Ras, (B) Rho-A, (C) p53, (D) Bax and (E) $B c l-x L$ gene expression in MCF-7 cell line. Bars represent the mean \pm SEM of three independent experiments ( $(\mathrm{P}<0.05)$. 
A

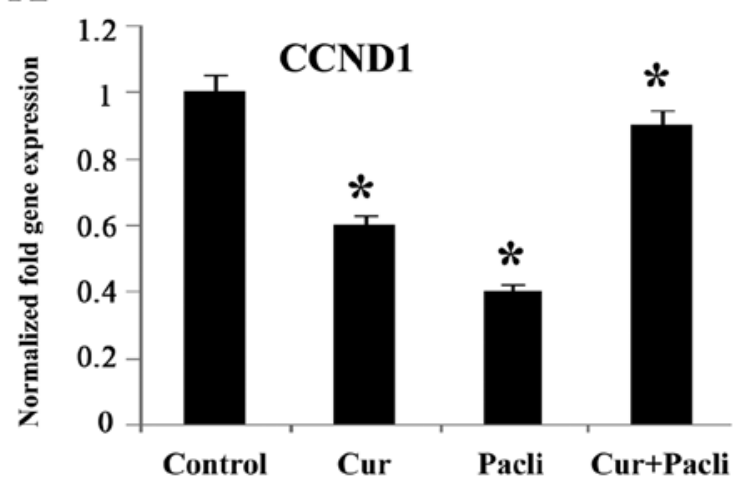

C

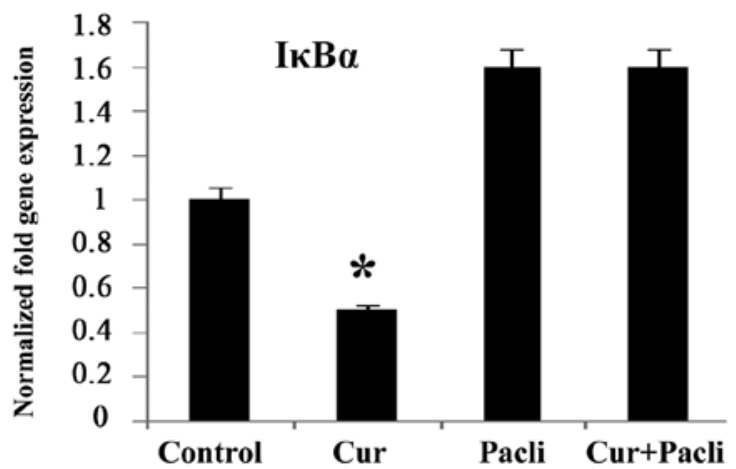

B

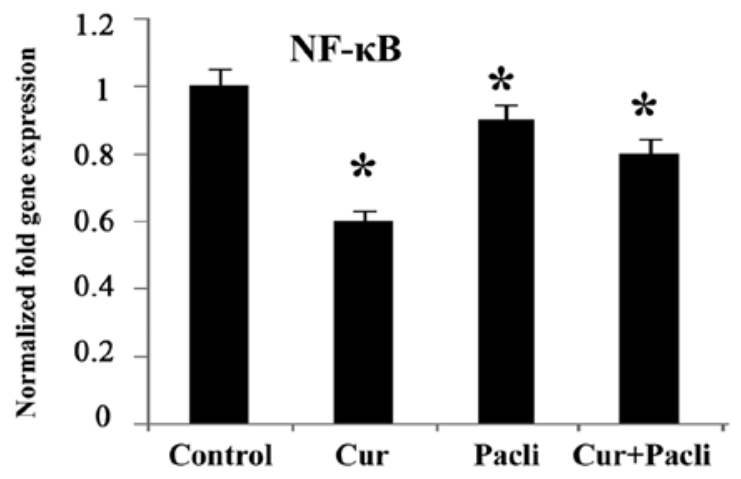

D

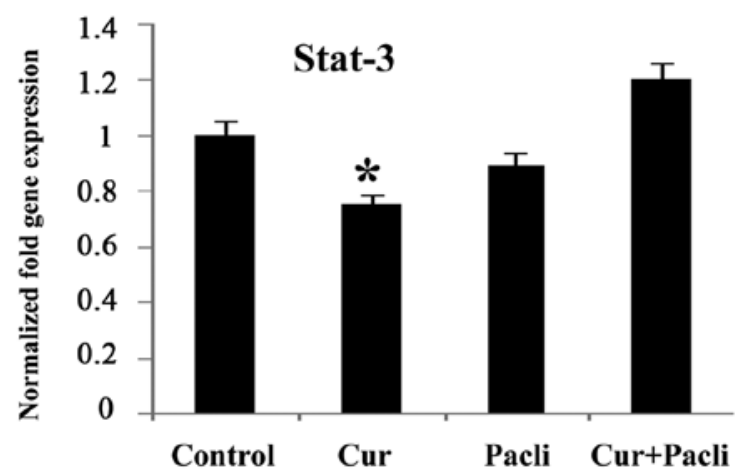

Cur: $15 \mu \mathrm{M}$

Pacli: 120 nM

\section{MCF-7}

Figure 3. Effect of curcumin $(15 \mu \mathrm{M})$ and paclitaxel $(120 \mathrm{nM})$ on gene expression analyzed by RT-qPCR on (A) $C C N D 1$, (B) $N F$ - $\kappa B$, (C) $I \kappa B \alpha$, (D) Stat-3 gene expression in MCF-7 cell line. Bars represent the mean \pm SEM of three independent experiments (" $\mathrm{P}<0.05$ versus control cells).

A
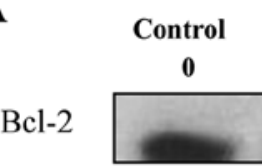

Pacli 120

acli Cur

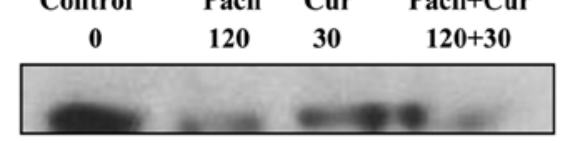
$26 \mathrm{kDa}$

$\beta$-actin

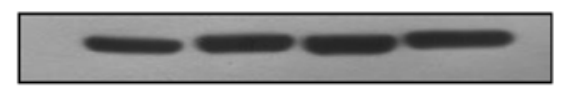
$42 \mathrm{kDa}$
C

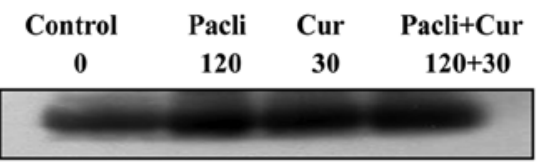
$23 \mathrm{kDa}$

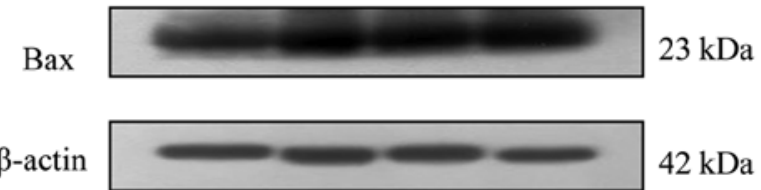

B

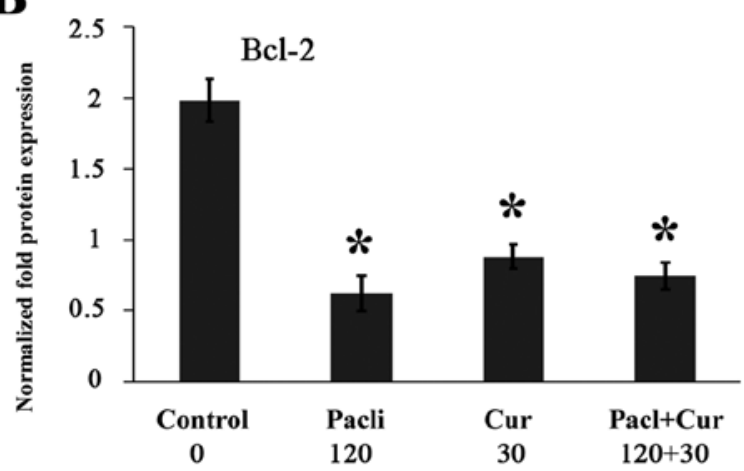

D

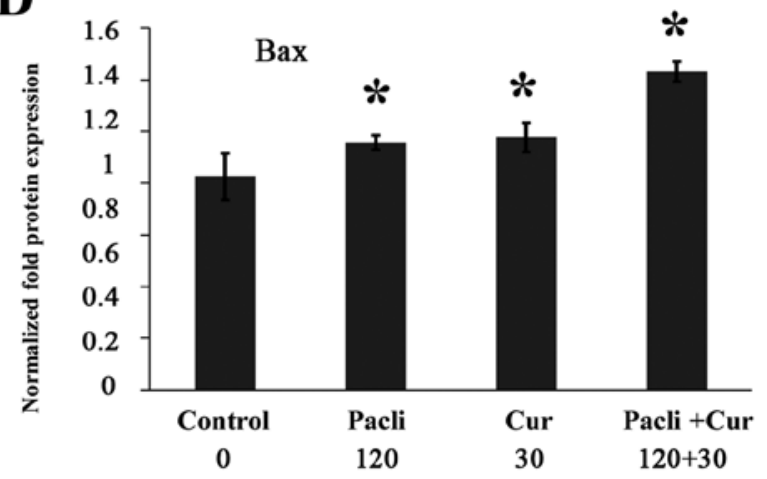

MCF-7

Figure 4. Western blot analysis of (A) Bcl-2 and (C) Bax protein expression in MCF-7 cell line treated with paclitaxel (120 nM) and curcumin (30 $\mu \mathrm{M})$. $\beta$-actin was used as control for loading. Western blotting results were quantified with Adobe Photoshop program and were expressed as average density to $\beta$-actin. (B and D) Bars represent the mean \pm SEM of three independent experiments $\left({ }^{*} \mathrm{P}<0.05\right)$. 


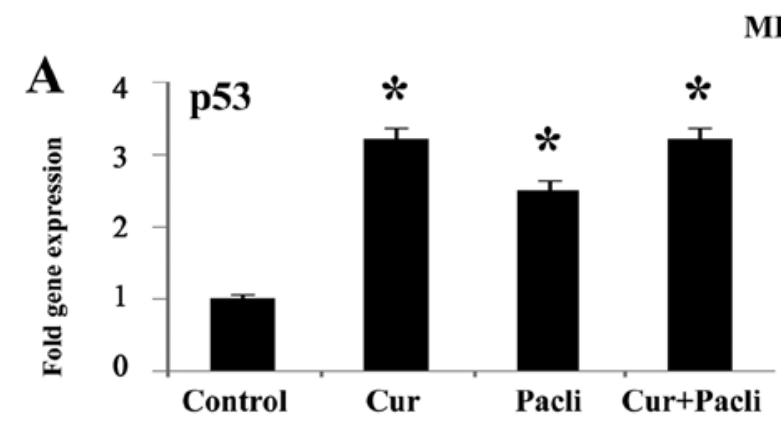

MDA-MB-231
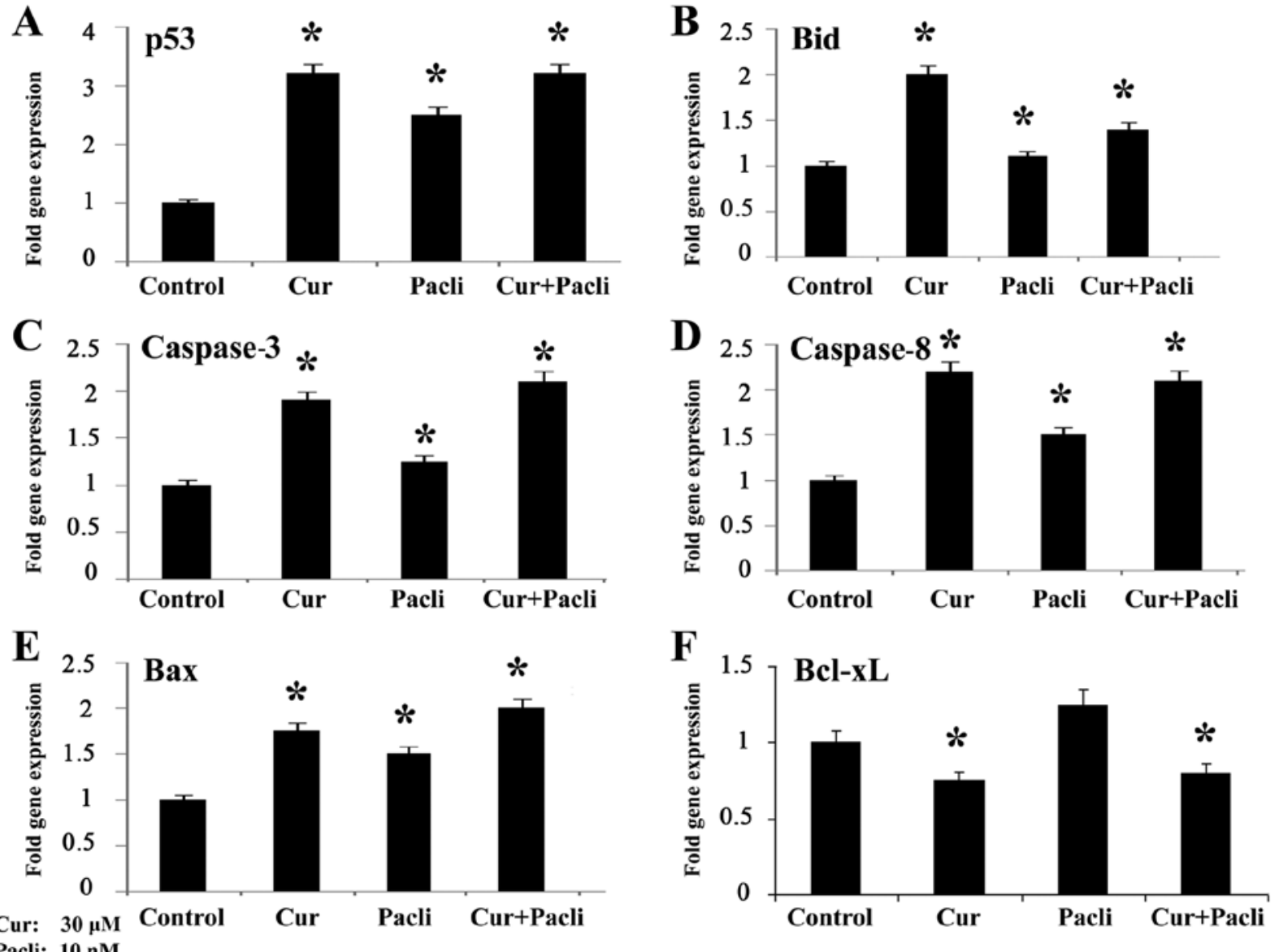

Pacli: $10 \mathrm{nM}$

Figure 5. Effect of curcumin $(30 \mu \mathrm{M})$ and paclitaxel $(10 \mathrm{nM})$ on gene expression analyzed by RT-qPCR on (A) p53, (B) Bid, (C) caspase-3, (D) caspase-8, (E) Bax and (F) Bcl-xL gene expression in MDA-MB-231 cell line. Bars represent the mean \pm SEM of three independent experiments (* $<<.05)$.

A

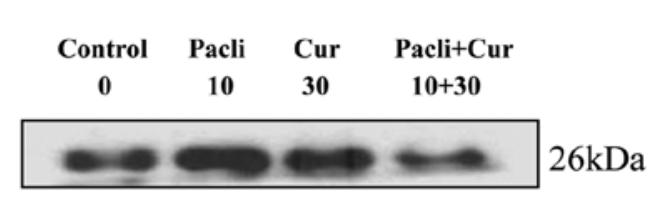

Bcl-2

$\beta$-actin

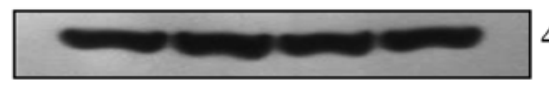

$42 \mathrm{kDa}$

B

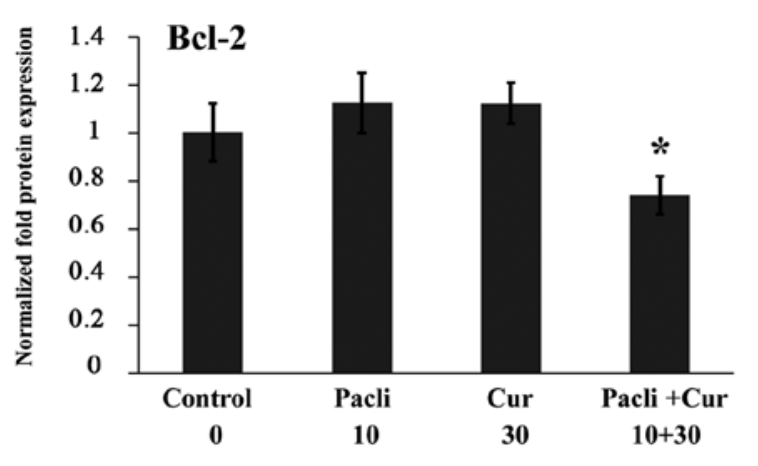

C

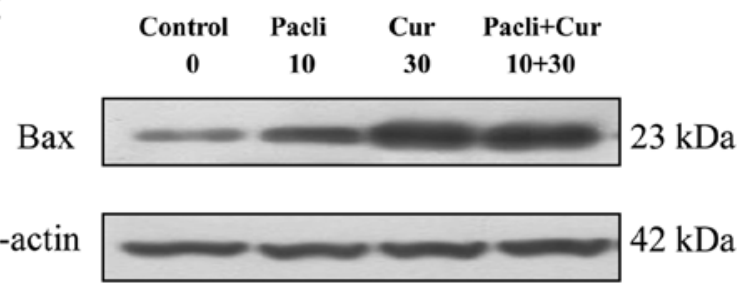

D

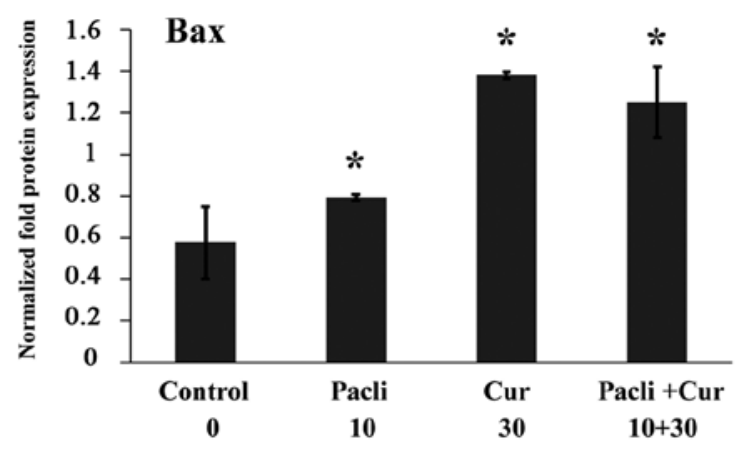

MDA-MB-231

Figure 6. Western blot analysis of (A) Bcl-2 and (C) Bax protein expression in MDA-MB-231 cell line treated with paclitaxel (10 $\mathrm{nM}$ ) and curcumin ( $30 \mu \mathrm{M})$. $\beta$-actin was used as control for loading. Western blotting results were quantified with Adobe Photoshop program and were expressed as average density to $\beta$-actin. (B and D) Bars represent the mean \pm SEM of three independent experiments $\left({ }^{*} \mathrm{P}<0.05\right)$. 
$(120 \mathrm{nM})$ significantly $(\mathrm{P}<0.05)$ decreased $c$-Ha-Ras, Rho-A, p53 and $B c l-x L$ gene expression in comparison to control and substances alone in MCF-7 cells as seen in Fig. 2A-D. Gene expression indicated that curcumin $(15 \mu \mathrm{M})$ and paclitaxel $(120 \mathrm{nM})$ alone significantly $(\mathrm{P}<0.05)$ increased Bax expression in comparison to control and substances alone in MCF-7 as seen in Fig. 2D.

Curcumin and paclitaxel alone and both combined significantly $(\mathrm{P}<0.05)$ decreased CCND1 (Fig. $3 \mathrm{~A})$ and NF- $\mathrm{\kappa B}$ (Fig. 3B), whereas curcumin alone decreased $I \kappa B \alpha$ and Stat-3 gene expression (Fig. 3C) and paclitaxel alone and combined increased them (Fig. 3D) in MCF-7 cells in comparison to control.

Effect of curcumin and paclitaxel on protein expression by western blot analysis in MCF-7 breast cancer cell line. Results indicated that either paclitaxel at $120 \mathrm{nM}$ or curcumin at $30 \mu \mathrm{M}$ alone and combined (Fig. 4A and B) significantly decreased Bcl-2 and increased Bax protein expression (Fig. 4C and D) in MCF-7, in comparison to control corroborating the apoptotic effect of these substances. Normalized fold protein expression is presented in graphs of Fig. 4B and D.

Effect of curcumin and paclitaxel on gene expression in MDA-MB-231 breast cancer cell line. Gene expression analyzed by RT-qPCR in MDA-MB-231 cells is shown in Fig. 5 where results indicate that curcumin at $30 \mu \mathrm{M}$ alone and combined with paclitaxel at $10 \mathrm{nM}$ significantly $(\mathrm{P}<0.05)$ increased p53 (Fig. 5A), Bid (Fig. 5B), caspase-3 (Fig. 5C), caspase-8 (Fig. 5D) and Bax (Fig. 5E) gene expression, whereas Bcl-xL decreased such expression (Fig. 5F) in comparison to control.

Effect of curcumin and paclitaxel on protein expression by western blot analysis in MDA-MB-231 breast cancer cell line. Results indicated that paclitaxel at $10 \mathrm{nM}$ and curcumin at $30 \mu \mathrm{M}$ combined significantly $(\mathrm{P}<0.05)$ decreased $\mathrm{Bcl}-2$ protein expression in comparison to control and either substance alone. However, either substance alone and combined increased Bax protein expression in MDA-MB-231 corroborating the apoptotic effect of these substances (Fig. $6 \mathrm{~A}$ and $\mathrm{C}$ ). Normalized fold protein expression is presented in graphs of Fig. 6B and D.

\section{Discussion}

Chemotherapy in breast cancer fails due to resistance to drugs. Chemotherapeutic strategies are now making use of combined active compounds where they are believed to be more active as compared to the single agent itself. Therefore, the efficacy of treatment would increase and the possibility of toxic effect might be lowered due to the extremely low usage of drug (42). A phytochemical such as curcumin can be used in a therapeutic modality as it elicits antitumor effects. Curcumin is a natural compound derived from turmeric (Curcuma longa) and exhibits an antitumorigenic effect on various cancers. Curcumin and paclitaxel effect was evaluated with the luminal MCF-7 and the basal-like MDA-MB-231 cells, respectively, these cell lines are positive and negative for hormonal receptors $\left(\mathrm{ER}^{+} \mathrm{PR}^{+}\right.$and $\mathrm{HER} 2^{+}$), respectively.
MCF-7 cells had longer DT when paclitaxel was combined with curcumin at low doses than control, indicating that a therapeutic modality like this would benefit the response of patients to treatment. Similar results were observed with MDA-MB-231 cells with low and high doses of paclitaxel in combination with low and high doses of curcumin. All the doses used significantly decreased the rate of growth of cells above its controls as indicated after several passages. Since growth inhibitory effect from combining paclitaxel with curcumin was more effective than either agent alone it seems that curcumin potentiates the apoptotic effects of paclitaxel in MCF-7 and MDA-MB-231 cell lines.

Curcumin combined with paclitaxel decreased c-Ha-Ras, Rho- $A$ and $p 53$ gene expression in comparison to control and substances alone in MCF-7 cell line. This is the first report that demonstrated that an antioxidant as curcumin and a chemotherapeutic drug reduces c-Ha-Ras, Rho-A and p53 gene expression. Gene expression levels supported the idea that paclitaxel induces changes in important signaling pathways.

Studies have indicated that curcumin is a pharmacologically safe compound, it has a therapeutic potential in preventing breast cancer metastasis possibly through suppression of NF- $\kappa B$ (43). Since curcumin suppresses NF- $\kappa B$ activation and most chemotherapeutic agents activate genes that mediates cell survival, proliferation, invasion, and metastasis (43), we analyzed whether curcumin would potentiate the effect of chemotherapy in breast cancer cell lines. Thus, curcumin decreased expression of NF- $\mathrm{KB}$ supporting the conclusion of other reports (44) that the mechanism of growth inhibition induced by combined effect of paclitaxel and curcumin is through NF- $\mathrm{KB}$ inhibition. It was demonstrated that curcumin suppressed the paclitaxel-induced NF- $\mathrm{KB}$ pathway in breast cancer cells by inhibiting lung metastasis of human breast cancer in nude mice (43).

Curcumin combined with paclitaxel decreased Bcl-xL gene expression in comparison to control and either substance alone in MCF-7 cell line. Other authors reported on the capability of inducing apoptosis in MCF-7 by several drugs (45). On the other hand, either substance alone increased Bax expression in comparison to control and either substance alone in MCF-7 cells. Curcumin, paclitaxel and combination of both decreased CCND1, whereas either substance alone decreased I $\mathrm{B} \alpha$ and Stat-3 gene expression in MCF-7 cells in comparison to control. Results indicated that either substance alone as curcumin and paclitaxel as well as combined decreased $\mathrm{Bcl}-2$ and increased Bax protein expression in comparison to control in MCF-7 cells, corroborating the apoptotic effect of these substances. It has also been suggested that inhibition of activity of proteins may improve the efficacy of chemotherapeutic agents (44).

It has been shown that curcumin induced apoptosis in breast cancer cells and delayed the outgrowth of mammary tumors in neu transgenic mice (46). The combination of docosahexaenoic acid and curcumin inhibited 7,12-dimethylbenz(a)anthracene (DMBA)-induced mammary tumorigenesis in mice (47). In addition, curcumin can reverse multidrug resistance in human colon carcinomas and lung cancer cells in vitro and in vivo $(48,49)$. Authors have shown that curcumin can inhibit epithelial mesenchymal transition by affecting transcription factors as E-cadherin and Vimentin genes and invasive capabilities in breast cancer cell lines $(50,51)$. 
When MDA-MB-231 cell line was analyzed it was found that curcumin alone and combined with paclitaxel increased p53, Bid, caspase-3, caspase-8 and Bax gene expression, whereas $B c l-x L$ decreased such expression in comparison to control. Results indicated that paclitaxel and curcumin combined decreased Bcl-2 protein expression in comparison to control and either substance alone. However, either substance alone and combined increased Bax protein expression in MDA-MB-231 corroborating the apoptotic effect of these substances. Curcumin decreased expression of apoptotic genes such as caspase-3, caspase-8, and other genes such as cyclin DI.

We demonstrated that curcumin increased the sensitivity of MCF-7 and MDA-MB-231 cells to chemotherapeutic drugs as paclitaxel. It has been proposed that combined effect of natural products may improve the effectiveness of treatment in the process of proliferation of cancer cells (42).

Several studies have aimed to delineate the complex molecular background of breast cancer, which has advanced personalized treatment approaches and enabled the development of several agents that target specific molecular aberrations associated with breast cancer. Nevertheless, tumor heterogeneity poses obvious impediments to the successful clinical development of targeted agents. The combined anticancer activities of a compound of natural origin such as curcumin has been examined in combination with a chemotherapy drug such as paclitaxel and it was observed that paclitaxelcurcumin compound exhibited synergistic growth inhibition and induced significant apoptosis in MCF-7 and MDA-MB231 cell lines. In conclusion, curcumin may be of considerable value in synergistic therapy of cancer since it may reduce the associated toxicity and it has a therapeutic potential with a drug such as paclitaxel in breast cancer.

\section{Acknowledgements}

The technical support of Guiliana Rojas, Georgina Vargas and secretarial assistance and suggestions of Leodán A. Crispin and Richard Ponce-Cusi are greatly appreciated. This study was supported by grant support FONDECYT no. 1120006 (G.M.C.) and Ministerio de Educación de Chile - Convenio de Desempeño (UTA-GMC).

\section{References}

1. Ferlay J, Steliarova-Foucher E, Lortet-Tieulent J, Rosso S, Coebergh JW, Comber H, Forman D and Bray F: Cancer incidence and mortality patterns in Europe: Estimates for 40 countries in 2012. Eur J Cancer 49: 1374-1403, 2013.

2. Calaf GM, Echiburú-Chau C, Roy D, Chai Y, Wen G and Balajee AS: Protective role of curcumin in oxidative stress of breast cells. Oncol Rep 26: 1029-1035, 2011.

3. Calaf GM, Echiburú-Chau C, Wen G, Balajee AS and Roy D: Effect of curcumin on irradiated and estrogen-transformed human breast cell lines. Int J Oncol 40: 436-442, 2012.

4. Joe B, Vijaykumar M and Lokesh BR: Biological properties of curcumin-cellular and molecular mechanisms of action. Crit Rev Food Sci Nutr 44: 97-111, 2004.

5. Gabizon A,PriceDC,Huberty J,BresalierRS andPapahadjopoulosD: Effect of liposome composition and other factors on the targeting of liposomes to experimental tumors: Biodistribution and imaging studies. Cancer Res 50: 6371-6378, 1990.

6. Fu Y, Li S, Zu Y, Yang G, Yang Z, Luo M, Jiang S, Wink M and Efferth T: Medicinal chemistry of paclitaxel and its analogues. Curr Med Chem 16: 3966-3985, 2009.
7. Okano J and Rustgi AK: Paclitaxel induces prolonged activation of the Ras/MEK/ERK pathway independently of activating the programmed cell death machinery. J Biol Chem 276: 19555-19564, 2001.

8. McGrogan BT, Gilmartin B, Carney DN and McCann A: Taxanes, microtubules and chemoresistant breast cancer. Biochim Biophys Acta 1785: 96-132, 2008.

9. Jin C, Wu H, Liu J, Bai L and Guo G: The effect of paclitaxelloaded nanoparticles with radiation on hypoxic MCF-7 cells. J Clin Pharm Ther 32: 41-47, 2007.

10. Barbacid M: ras genes. Annu Rev Biochem 56: 779-827, 1987.

11. Kasid A, Lippman ME, Papageorge AG, Lowy DR and Gelmann EP: Transfection of v-rasH DNA into MCF-7 human breast cancer cells bypasses dependence on estrogen for tumorigenicity. Science 228: 725-728, 1985.

12. Yu LLG and Gu JY: Advances in the role of Rho sub-family in tumor invasion. Fudan Univ J Med Sci 37: 617-619, 2010.

13. Hall A: Rho GTPases and the actin cytoskeleton. Science 279: 509-514, 1998.

14. DerMardirossian C and Bokoch GM: GDIs: Central regulatory molecules in Rho GTPase activation. Trends Cell Biol 15: 356-363, 2005.

15. Olofsson B: Rho guanine dissociation inhibitors: Pivotal molecules in cellular signalling. Cell Signal 11: 545-554, 1999.

16. Schmitt CA, Fridman JS, Yang M, Lee S, Baranov E, Hoffman RM and Lowe SW: A senescence program controlled by $\mathrm{p} 53$ and p16INK4a contributes to the outcome of cancer therapy. Cell 109: 335-346, 2002.

17. Vogelstein B, Lane D and Levine AJ: Surfing the p53 network. Nature 408: 307-310, 2000.

18. Hengartner MO: The biochemistry of apoptosis. Nature 407: 770-776, 2000.

19. Yonish-Rouach E, Grunwald D, Wilder S, Kimchi A, May E, Lawrence JJ, May P and Oren M: p53-mediated cell death: Relationship to cell cycle control. Mol Cell Biol 13: 1415-1423, 1993.

20. Miyashita T, Krajewski S, Krajewska M, Wang HG, Lin HK, Liebermann DA, Hoffman B and Reed JC: Tumor suppressor p53 is a regulator of bcl-2 and bax gene expression in vitro and in vivo. Oncogene 9: 1799-1805, 1994.

21. Miyashita T and Reed JC: Tumor suppressor p53 is a direct transcriptional activator of the human bax gene. Cell 80: 293-299, 1995.

22. Cory S and Adams JM: The Bcl2 family: Regulators of the cellular life-or-death switch. Nat Rev Cancer 2: 647-656, 2002.

23. García-Sáez AJ: The secrets of the Bcl-2 family. Cell Death Differ 19: 1733-1740, 2012.

24. González de Aguilar JL, Gordon JW, René F, de Tapia M, LutzBucher B, Gaiddon C and Loeffler JP: Alteration of the Bcl-x/ Bax ratio in a transgenic mouse model of amyotrophic lateral sclerosis: Evidence for the implication of the p53 signaling pathway. Neurobiol Dis 7: 406-415, 2000.

25. van Delft MF and Huang DC: How the Bcl-2 family of proteins interact to regulate apoptosis. Cell Res 16: 203-213, 2006.

26. Jürgensmeier JM, Xie Z, Deveraux Q, Ellerby L, Bredesen D and Reed JC: Bax directly induces release of cytochrome $c$ from isolated mitochondria. Proc Natl Acad Sci USA 95: 4997-5002, 1998.

27. Placzek WJ, Wei J, Kitada S, Zhai D, Reed JC and Pellecchia M: A survey of the anti-apoptotic Bcl-2 subfamily expression in cancer types provides a platform to predict the efficacy of $\mathrm{Bcl}-2$ antagonists in cancer therapy. Cell Death Dis 1: e40, 2010.

28. Davids MS and Letai A: Targeting the B-cell lymphoma/ leukemia 2 family in cancer. J Clin Oncol 30: 3127-3135, 2012.

29. Walensky LD: From mitochondrial biology to magic bullet: Navitoclax disarms BCL-2 in chronic lymphocytic leukemia. J Clin Oncol 30: 554-557, 2012.

30. Dai Y, Lawrence TS and Xu L: Overcoming cancer therapy resistance by targeting inhibitors of apoptosis proteins and nuclear factor-kappa B. Am J Transl Res 1: 1-15, 2009.

31. Han J, Sun M, Cui Y, Wang T, Zhang W, Guo M, Zhou Y, Liu W, Zhang M, Duan J, et al: Kushen flavonoids induce apoptosis in tumor cells by inhibition of NF-kappaB activation and multiple receptor tyrosine kinase activities. Phytother Res 21: 262-268, 2007.

32. Wulczyn FG, Naumann $M$ and Scheidereit C: Candidate proto-oncogene bcl-3 encodes a subunit-specific inhibitor of transcription factor NF-kappa B. Nature 358: 597-599, 1992.

33. Bours V, Franzoso G, Azarenko V, Park S, Kanno T, Brown K and Siebenlist U: The oncoprotein Bcl-3 directly transactivates through kappa B motifs via association with DNA-binding p50B homodimers. Cell 72: 729-739, 1993. 
34. Dobrzanski P, Ryseck RP and Bravo R: Differential interactions of Rel-NF-kappa B complexes with I kappa B alpha determine pools of constitutive and inducible NF-kappa B activity. EMBO J 13: 4608-4616, 1994.

35. Baldwin AS Jr: The NF-kappa B and I kappa B proteins: New discoveries and insights. Annu Rev Immunol 14: 649-683, 1996.

36. Cheng JD, Ryseck RP, Attar RM, Dambach D and Bravo R: Functional redundancy of the nuclear factor kappa B inhibitors I kappa B alpha and I kappa B beta. J Exp Med 188: 1055-1062, 1998.

37. Huxford T, Huang DB, Malek S and Ghosh G: The crystal structure of the IkappaBalpha/NF-kappaB complex reveals mechanisms of NF-kappaB inactivation. Cell 95: 759-770, 1998.

38. Tam WF and Sen R: IkappaB family members function by different mechanisms. J Biol Chem 276: 7701-7704, 2001.

39. Hoffmann A, Levchenko A, Scott ML and Baltimore D: The IkappaB-NF-kappaB signaling module: Temporal control and selective gene activation. Science 298: 1241-1245, 2002.

40. Anest V, Hanson JL, Cogswell PC, Steinbrecher KA, Strahl BD and Baldwin AS: A nucleosomal function for IkappaB kinasealpha in NF-kappaB-dependent gene expression. Nature 423 . 659-663, 2003.

41. Calaf $G$ and Russo J: Transformation of human breast epithelial cells by chemical carcinogens. Carcinogenesis 14: 483-492, 1993.

42. Zhan Y, Chen Y, Liu R, Zhang H and Zhang Y: Potentiation of paclitaxel activity by curcumin in human breast cancer cell by modulating apoptosis and inhibiting EGFR signaling. Arch Pharm Res 37: 1086-1095, 2014.

43. Aggarwal BB, Shishodia S, Takada Y, Banerjee S, Newman RA, Bueso-Ramos CE and Price JE: Curcumin suppresses the paclitaxel-induced nuclear factor-kappaB pathway in breast cancer cells and inhibits lung metastasis of human breast cancer in nude mice. Clin Cancer Res 11: 7490-7498, 2005.
44. Kang HJ, Lee SH, Price JE and Kim LS: Curcumin suppresses the paclitaxel-induced nuclear factor-kappaB in breast cancer cells and potentiates the growth inhibitory effect of paclitaxel in a breast cancer nude mice model. Breast J 15: 223-229, 2009.

45. Choudhuri T, Pal S, Agwarwal ML, Das T and Sa G: Curcumin induces apoptosis in human breast cancer cells through p53-dependent Bax induction. FEBS Lett 512: 334-340, 2002.

46. Masuelli L, Benvenuto M,Fantini M, Marzocchella L, Sacchetti P, Di Stefano E, Tresoldi I, Izzi V, Bernardini R, Palumbo C, et al: Curcumin induces apoptosis in breast cancer cell lines and delays the growth of mammary tumors in neu transgenic mice. J Biol Regul Homeost Agents 27: 105-119, 2013.

47. Siddiqui RA, Harvey KA, Walker C, Altenburg J, Xu Z, Terry C, Camarillo I, Jones-Hall Y and Mariash C: Characterization of synergistic anti-cancer effects of docosahexaenoic acid and curcumin on DMBA-induced mammary tumorigenesis in mice. BMC Cancer 13: 418, 2013.

48. Lu WD, Qin Y, Yang C, Li L and Fu ZX: Effect of curcumin on human colon cancer multidrug resistance in vitro and in vivo. Clinics (Sao Paulo) 68: 694-701, 2013.

49. Thiyagarajan S, Thirumalai K, Nirmala S, Biswas $\mathbf{J}$ and Krishnakumar S: Effect of curcumin on lung resistance-related protein (LRP) in retinoblastoma cells. Curr Eye Res 34: 845-851, 2009.

50. Gallardo M and Calaf GM: Curcumin and epithelial-mesenchymal transition in breast cancer cells transformed by low doses of radiation and estrogen. Int J Oncol 48: 2534-2542, 2016.

51. Gallardo M and Calaf GM: Curcumin inhibits invasive capabilities through epithelial mesenchymal transition in breast cancer cell lines. Int J Oncol 49: 1019-1027, 2016. 